\title{
Mergers, acquisitions and the evolution of construction professional services firm
}

Article

Accepted Version

Connaughton, J., Meikle, J. and Teerikangas, S. (2015) Mergers, acquisitions and the evolution of construction professional services firm. Construction Management and Economics, 33 (2). pp. 146-159. ISSN 0144-6193 doi: https://doi.org/10.1080/01446193.2015.1037325 Available at https://centaur.reading.ac.uk/67325/

It is advisable to refer to the publisher's version if you intend to cite from the work. See Guidance on citing.

Published version at: http://dx.doi.org/10.1080/01446193.2015.1037325

To link to this article DOI: http://dx.doi.org/10.1080/01446193.2015.1037325

Publisher: Taylor and Francis

All outputs in CentAUR are protected by Intellectual Property Rights law, including copyright law. Copyright and IPR is retained by the creators or other copyright holders. Terms and conditions for use of this material are defined in the End User Agreement.

\section{www.reading.ac.uk/centaur}

\section{CentAUR}

Central Archive at the University of Reading 
Reading's research outputs online 
MERGERS, ACQUISITIONS AND THE EVOLUTION OF CONSTRUCTION

PROFESSIONAL SERVICE FIRMS

Connaughton, J., Meikle, J. and Teerikangas, S.

\begin{abstract}
Whilst mergers and acquisitions are a favoured means of strategic renewal and expansion for firms, scant academic attention has been placed on the growth patterns of construction professional services firms (CPSFs). This paper focuses on the role of mergers and acquisitions in the evolution of CPSFs. The findings are based on an analysis of the growth patterns of the top 25 CPSFs in the United Kingdom between 1988 and 2013. Since the 1990s, the increase in merger and acquisition activity has shaped the size, international presence, and multi-disciplinary reach of the major CPSFs. However, CPSFs differ with respect to the intensity with which mergers and acquisitions are pursued. Whilst large, public limited companies are active acquirers, smaller and/or privately-owned firms succeed in growing with a more selective acquisitive strategy, as they tend to rely more on organic growth. The findings call construction economists to attend to how acquisitions are radically changing the construction landscape and its main players. As the competitive advantage of firms is increasingly human capital-based, the example of the privately-owned CPSFs that rely on organic modes of growth prompts a critical rethink of the role of mergers and acquisitions in firm growth.
\end{abstract}

Key words: merger, acquisition, construction professional services firm, evolution, strategy, growth. 


\section{INTRODUCTION}

Mergers and acquisitions (M\&As) have become primary vehicles of strategic renewal and expansion, as firms seek worldwide reach and positioning in a competitive global arena (Hitt et al., 2012; Angwin, 2012). In 2013, the global value of M\&A transactions reached USD 2.2 trillion (Mergermarket, 2013). Paralleling the appeal of M\&A amidst executives, the phenomenon has sparked a scholarly interest (see reviews in Haleblian et al., 2009; Ghauri and Buckley, 2003; Faulkner et al., 2012). In a review of strategic and financial studies of M\&A, Haleblian et al. (2009) observe that extant theorizing considers mergers and acquisitions generically, disregarding sectoral or industry characteristics. As with management and organization theorizing (Walsh et al., 2006), the bulk of academic work on M\&As is based on cross-sectional, publicly available data, concerning transactions by large, listed firms, across industries (Cartwright et al., 2012).

A case in point concerns the study of M\&A in construction, where the academic study of firm growth strategies (Chinowski and Meredith, 2000; Cheah et al., 2004), including M\&A (Carrillo, 2001), remains scant. Kreitl et al.'s (2002) study of the growth patterns of the top 100 European engineering consulting firms 1990-1998 highlights that most $(62.5 \%)$ of this growth was achieved organically, a third (32.5\%) via M\&As, whereas the use of joint ventures was small (4.5\%). In a follow-up study, Kreitl and Obderndorfer (2004) observe that M\&As are driven by product/service/client or market diversification motives. Delaney and Wamuziri's (2004) study of UK contractors' financial performance following M\&A confirms findings from other industries (King et al., 2004): whilst target firms benefit in the short-term, few if any financial benefits accrue to acquiring firms. Practice-based papers focus on construction M\&A management, as regards pre-merger integration planning (Gialketsis, 1991), acquisition management (Hensey, 1992, 2000), or cross-border knowledge transfer (Bröchner et al., 2004). This leads us to observe that an appreciation of the characteristics and 
dynamics of M\&A activity in construction is emerging, yet the field lacks maturity. Whether M\&A in construction follow the patterns observed in generic M\&A theorizing is a question warranting further inquiry.

There are recent exceptions to a sector-agnostic treatment of M\&A in the management literature as regards technology-based acquisitions (Ranft and Lord, 2002; Graebner et al., 2010) and mergers by professional service firms (Greenwood et al., 1994; Empson, 2001; Fairclough and Fairclough, 2012). We draw on this line of inquiry to study construction professional services firms (CPSFs). Whilst professional services firms have received scholarly attention (Maister, 1993; Brock, 2006), recent contributions (Smyth, 2011; Connaughton and Meikle, 2013) suggest a dearth of emphasis on CPSFs. Building on Jewell et al. (2010) and Connaughton and Meikle (2013), we define CPSFs as those firms included under categories 71 (Architectural and engineering activities, technical testing and analysis) and 74 (Other professional, scientific and technical activities) in the UK Standard Industrial Classification (SIC) (Office of National Statistics, 2007).

As regards $\mathrm{M} \& \mathrm{~A}$, the growth motives and patterns of construction engineering consultancies 1990-1998 have been documented (Kreitl and Obderndorfer, 2004; Kreitl et al., 2002). Since 1998, beyond anecdotal evidence (e.g. Smyth, 2011; Meikle, 2011), academic reviews of the M\&A activity of CPSFs have not been undertaken. This is the theoretical gap motivating the paper. Our aim is to identify the M\&A-related growth patterns and evolution of the top 25 UK-based CPSFs 1988-2013. This enables us to provide one measure of how much the UK construction industry has changed over the past 25 years and how M\&A activity has shaped this change. Based on desktop research and three case studies, we identify three M\&A-related growth profiles amid the top UK-based CPSFs. Going forward, we call researchers in construction economics and management to note how acquisitive activity is shaping the industry and its players. We further observe that three 'outlier' firms have 
achieved dominant market positions without significant M\&A activity. In an increasingly knowledge and human capital-based era (Barney et al., 2001), is it time to rethink the role of M\&As in firms' growth strategies?

\section{RESEARCH METHOD AND SETTING}

\section{Research approach}

Our paper is based on an inductive and historical analysis of the evolutionary growth patterns of major UK-based CPSFs 1988-2013. An inductive approach is common in the social sciences, when dealing with areas of inquiry with little prior knowledge (Glaser and Strauss, 1967). Given that our analysis bears a historical and evolutionary orientation, we draw on management history, where the analysis of industries' evolution patterns (e.g. Lamberg and Tikkanen, 2006) using historical data, including annual reports, websites and public reports, is common practice.

\section{Data collection}

Following Connaughton and Meikle (2013), our empirical sample is based on the larger UKbased CPSFs (Table 1); they feature in the annual league table published by the UK-based trade magazine Building. Despite its shortcomings, the advantages of this data source are that it (1) is readily available, (2) spans the professional disciplines in the built environment, and (3) provides access to annual data on CPSFs since 1988.

\section{INSERT TABLE 1 ABOUT HERE}

We coupled this desktop analysis with multiple case analysis (Yin, 2004; Eisenhardt, 1989) using open-ended interviews with senior executives at top management or board levels from three firms - Arup, Mace and Mott MacDonald. These three firms were identified as outliers in our sample. The term 'outlier' reflects the observation that the growth patterns of 
these firms differed from those of the other major players. Purposeful, theoretical sampling is recommended in grounded theory to access a studied phenomenon from a diverse empirical basis. Stake (1995) terms such outliers 'instrumental case studies'; they enable exploring a research question in a particular context.

The interviews lasted between one to two hours; they were attended by one or two authors. The aim of the interviews was to refine the findings emerging from the desktop analysis by tapping into the qualitative, implicit experience of these firms, and to probe the rationales guiding their evolutionary choices since 1988. All interviewees have witnessed this period of growth in the case firms and were in a position to discuss the topic.

Our third source of data consists of industry expertise. Two of the paper's authors, through their careers in CPSFs, bear first-hand experience in having observed the transformation of the UK construction sector over the past 25 years. This industry expertise was combined with the third author's academic M\&A expertise across industries. This insider-outsider approach (Bartunek and Louis, 1996) further characterized our research design. This approach differs from much M\&A research, dominated by either academic or consulting-led enquiries.

\section{Data analysis}

Our analysis proceeded in several rounds. We began by scoping the size of the 100 largest CPSFs using the Building Magazine 2013 league table. Our analysis was capped at the top 25 firms; we observed M\&A activity to characterize the larger players in the industry; for firms below the top 20, M\&A activity becomes rare to non-existent. Using these 25 firms, we sought to capture their evolutionary dynamics. We excluded property management and real estate firms from the sample (i.e. Capita, CBRE, GVA Grimley, Deloitte Real Estate and Jones Lang Lasalle). We considered Faithful \& Gould as part of Atkins, though it features as 
an independent entry in the league table. The sample of 25 firms used for our analysis represents thus the top 31 players (Building Magazine, 2013).

Focusing on the top 25 firms, we undertook a firm-by-firm analysis of each CPSF's M\&A activity. We relied primarily on publicly available online material on the firms' webpages, whether sourced from (1) the firm's historical outline, (2) its M\&A activity, or via (3) individual acquisition-related news items. This resulted in 34 pages of material on the sampled firms' M\&A activity. The ensuing analysis led us, inductively, to categorize the growth patterns of these CPSFs. In a third phase, we observed that the above categorization mirrored the firms' disciplinary breadth, governance style, and international reach. We returned to desktop research to re-analyse the studied firms from these perspectives. It is at this stage that we identified three outliers in the sample of 25 and conducted interviews in these firms. After the write-up of the interviews, we undertook a cross-case analysis (Yin, 2004; Eisenhardt, 1989). This iterative approach led us to appreciate the evolutionary pattern of growth amid the major CPSFs.

\section{SETTING THE EVOLUTIONARY CONTEXT 1988-2013}

\section{Major construction professional services firms 1988 vs. 2013}

League tables for CPSFs appeared in the 1988 Building Magazine. The introductory text to its first article is telling:

"Some say league tables, such as the ones published here, should not be compiled....

... Why do building professionals like to be so secretive? Why are people so determined to make such a mystery of their practice or company's status. . . . . . And yet there are practices which have even refused to send us their corporate brochure, so determined are they to prevent us from publishing their status." 
The data presented was limited to staff numbers and the number of office locations. A number of major firms declined to participate (e.g. quantity surveyors EC Harris, Gardiner and Theobald and Rider Hunt, and engineers Mott MacDonald, Travers Morgan Scott Wilson and Gibbs). Over half of the top ten firms in 1988 were architectural design firms, but only one, Building Design Partnership (BDP), was present by 1990.

\section{INSERT TABLE 2 ABOUT HERE}

Table 2 compares total UK staff and total worldwide staff averaged over three surveys (1988 to 1990) and equivalent data in 2013 for the top ten firms. The table highlights that many of the 1988 firms exist in 2013 (e.g. Arup, Mott MacDonald and Atkins), whereas others have been subsumed (e.g. Scott Wilson by URS and Davis Langdon by Aecom). Total numbers of staff in the UK have increased by an average of over $5.5 \%$ per annum over the period, with worldwide staff numbers increasing at over twice that rate. Geographical focus in the early years, measured by the proportion of staff based in the UK, was generally national - averaging $73 \%$ while, in 2013, it averaged 19\%. The firms with greater geographical presence in the early years were quantity surveying based. Most firms had over $60 \%$ of their staff based in the UK, and all of them were UK owned. By contrast, the 2013 firms have most of their staff outside the UK and half of them are non-UK firms.

\section{7-2013: A period of industry consolidation for CPSFs}

It is difficult to accurately assess consolidation amid the top CPSFs, largely because of a lack of comparable data. The approach adopted here is to calculate the change in the share of revenue taken by the top four and five CPSF firms over a period of time. This method has been used by authors to assess concentration in the contracting sector (e.g. Lowe, 2011). 
Table 3 sets out the reported fee income of the top 50 CPSFs in 1997, 2005 and 2013 respectively and the proportion of that income taken by the top four and five firms. Table 3 suggests a trend towards concentration, as an increasing proportion of total revenue is taken by the top few firms, from over 30\% in 1997 to over $40 \%$ in 2013 . This is consistent with other reports. Connaughton and Meikle (2013) indicate that staff numbers in the top 20 have more than doubled 1995-2011, representing an average annual increase of 5\%. Signs of consolidation amid quantity surveying firms are noted in Meikle (2011), as the proportion of RICS members employed in the top 10 quantity surveying firms grew from 5\% in 1988 to $17 \%$ in 2002. Nevertheless, the data in Table 3 ought to be treated with some caution. For one, it includes only fifty firms while the contracting studies include a minimum of 100 firms (Lowe, 2011). For another, the data is self-reported, and thus not necessarily consistent in content. Full sector concentration studies are difficult with CPSFs, as fee income data is not readily available for smaller firms. The data in Table 3 thus excludes the vast number of CPSFs below the top 50 .

\section{MERGERS AND ACQUISITIONS AND THE EVOLUTION OF CPSFS}

\section{Growth profiles of construction PSFs}

Our analysis of CPSFs' modes of growth since the end of the 1980s leads us to a three-fold categorization of their growth strategies. In this period, consistent with observations from other industries (Kolev et al., 2012), the use of acquisitions vs. mergers is more prevalent. Buckley and Ghauri (2002) suggest that $97 \%$ of M\&A activity in terms of transactions are acquisitions rather than mergers. We identify three profiles of CPSF growth in the 1988-2013 period, Table 4.

INSERT TABLE 4 ABOUT HERE 
Profile I: Active merger and acquisition activity. A quartile of the sampled 25 firms utilise mergers and acquisitions very actively as growth strategies. Extant research characterizes them as serial acquirers (Laamanen and Keil, 2008); such firms undertake well-considered acquisition programs to achieve their strategic growth targets (Keil, Laamanen and Makisalo, 2012).

Beyond a serial acquisition strategy, we observe that the largest players have selectively also undertaken major mergers. Indeed, four of these firms (Aecom, Arcadis, Jacobs and WSP) have undergone one or several mergers in addition to completing a stream of acquisitions since 1988. These four firms are ranked in 2013 within the top ten CPSFs. This is the only category of firms in the sample that appears to have actively pursued both mergers and acquisitions. Whilst smaller-scale acquisitions are undertaken frequently by these four players, their merger activity has been less frequent. These few mergers concern significantly larger transactions, though, combining two or more key players. Taking Aecom's example, formed through the 1990 merger of five individual firms boasting longstanding histories, Aecom has since undertaken more than 40 smaller-scale acquisitions in addition to recent mergers. Arcadis merged in the 1990s with US-based Geraghty \& Miller, followed by over 50 acquisitions. Jacobs merged in 1999 with Svedrup Corporation and has increased its acquisitive strategy since 2004 .

Profile II: Occasional acquirers. We term the next set of players 'occasional acquirers'. They include medium-sized players such as Parsons Brinckerhoff, Waterman and Gleeds ranked between 10-25 in the 2013 league table, and one smaller-sized player ranked \#25, Grontmij. These firms have not conducted mergers, relying instead on organic growth coupled with selective acquisitions. Their strategic growth relies on a much less frequent use of acquisitions as compared to the players in the previous category. 
Three outliers are identified in that they are ranked in the top ten in 2013, without being active acquirers. Mott MacDonald bears a recent history with mergers, as it was formed by a merger of Mott Hay \& Anderson and Sir M. MacDonald \& Partners. Its acquisition strategy has thereafter been selective. Arup and Mace are also outliers in this category. Ranked \#7 and \#9 respectively in the 2013 UK league table, both have avoided mergers, relying on organic growth coupled with a handful of selective acquisitions. We return to these three outlier firms' growth strategies later.

Profile III: Organic growth. A third category of CPSFs includes medium-sized players (such as Sweett Group, BDP, Buro Happold, and Foster and Partners) and most of the smaller players in the studied sample (such as Hoare Lea, Systech International, and Fairhurst). This category consists of firms that have not used acquisitions or mergers as modes of strategic growth; instead, they have largely grown organically.

\section{Mode of ownership driving M\&A activity}

Prior to the 1980s, the structure and management of CPSFs was largely controlled by the professional institutions, such as the RICS and the RIBA. Meikle (2011) and Connaughton and Meikle (2013) describe how the competition authorities removed restrictions on firm structures and ownership, permitted advertising and competition, and outlawed mandatory fee scales. At the same time, an array of financial, quality management, equality, health and safety and other requirements were imposed. Deregulation of the professions permitted firms to change their ownership, management and structure toward more corporate forms. This resulted in more corporate responses, including pressures for growth and enthusiasm for M\&A. Regulatory requirements also encouraged growth; smaller firms found it increasingly difficult to comply with requirements. 
These environmental changes prompted us to further our analysis. In Table 5, we assess how a firm's growth profile matches its mode of ownership. As firms have transitioned from private partnerships to globalized professional networks (Brock, 2006) owned by external shareholders, their M\&A activity has increased. Thus, active acquirers are owned by external shareholders, whereas firms grown organically remain privately owned. The occasional acquirers fall in between. This concurs with Ryan's argument (2012) about public limited ownership and external shareholding driving growth via M\&A.

\section{INSERT TABLE 5 ABOUT HERE}

\section{The changing nature of CPSFs via M\&A activity}

Having ascertained growth profiles in the UK-based CPSFs, we now analyse how these growth strategies have shaped the nature of the acquiring firms.

M\&A as a means of growth and industry leadership. The above analysis confirms that M\&A activity has enabled a growth in firm size 1988-2013. This growth has secured the maintenance of industry leadership for the firms involved: comparing the league table of CPSFs in 1988 vs. 2013, the key players have largely remained the same (Table 2). What has changed, though, is the size and ownership of these firms (Table 3).

Active acquiring characterizes the larger-sized CPSFs, i.e. most of the top ten industry players, including Atkins, URS, Aecom, Arcadis and Jacobs (Table 4). This contrasts with most of the smaller players (i.e. ranked under 14) that have largely grown organically, without acquisitive growth or mergers. WYG and Grontmij are exceptional smaller-sized players in that they are characterized respectively by active and partial acquisitive activity. The medium-sized industry players (i.e. 7-25) fall in-between. Whilst many of them are occasional acquirers, another set have largely relied on organic growth. Parsons Brinckerhoff, Waterman, Gleeds, and TPS are examples in the former category, whilst Sweett Group, BDP 
and Buro Happold illustrate the latter category. We observe that active M\&A activity results in industry leadership.

$M \& A$ as a strategy for securing disciplinary breadth. Beyond a growth in firm size, M\&A activity has enabled CPSFs to secure breadth across the services they provide by acquiring firms in other disciplines. A firm's degree of disciplinary breadth is related to its M\&A activity (Table 6). Whilst all firms began initially in the late $19^{\text {th }}$ or early/mid $20^{\text {th }}$ centuries as single disciplinary practices in engineering, architecture, or surveying, through M\&A activity, firms now span a broader disciplinary basis.

\section{INSERT TABLE 6 ABOUT HERE}

This is particularly the case of the 'active acquirers'. Through active merging and acquiring, they have expanded their disciplinary base either within their own discipline (e.g. engineering) and/or to neighbouring disciplines (e.g. quantity surveying, architecture, project management, facilities management, or real estate). Table 6 highlights that occasional acquirers present some, albeit a narrower, degree of multidisciplinarity. We term these 'multidisciplinary narrow' - i.e. firms that bear a strong base in their original discipline, but have expanded to a neighbouring discipline. In contrast, we observe that firms that have not resorted to M\&A activity remain largely single discipline or partly multidisciplinary.

M\&A as a strategy for securing international presence. Globalisation and internationalisation in construction professional services accelerated in the 1980s. British construction consultancies have worked internationally since the Second World War, mainly in the old British Empire. The launch of the Single European Market in 1992 led to UK firms moving into Europe and foreign firms moving into the UK. The UK recession in the late 1980s also encouraged the internationalization of CPSFs. Demand from emerging markets, particularly Asia and the Middle East, provided opportunities for cross-border expansion. 
M\&A activity has been a means of securing such international presence (Table 7). Whilst active acquirers exhibit broad international presence, with offices spanning the globe, the international presence of occasional and non-acquirers is not as marked. Some players have global presence, whilst others retain regional presence, spanning select countries only, or remain home market-based. Parallel to M\&A activity, CPSFs have internationalized via joint ventures and alliances, though the latter remains of lesser significance to CPSF growth than organic and M\&A growth (Kreitl et al., 2002).

INSERT TABLE 7 ABOUT HERE

\section{INDUSTRY LEADERSHIP WITH SELECTIVE M\&A ACTIVITY}

\section{- AN ANALYSIS OF OUTLIERS}

A closer look at the data led us to identify three outliers within the top ten CPSFs that, in contrast to their competitors, have adopted an occasional M\&A strategy (Table 4). These outliers are Arup, Mace and Mott MacDonald.

\section{Outlier \#1: Mott MacDonald}

Formed in 1989 as a result of a merger between Sir M MacDonald and Partners (a water engineering consultancy) and Mott Hay and Anderson (a transportation consultancy), Mott MacDonald (MMD) ranks today as one of the UK's largest engineering consultancies. MMD has grown steadily since the merger, maintaining a leading presence amid the Building top 25 consultancies. MMD is predominantly an engineering business, with $85 \%$ of revenues attributable to engineering activities. The firm's services are delivered across 10 sectors and managed globally through 4 regions. Group turnover in 2012 was $£ 1.1$ billion.

Mott MacDonald (MMD) is unusual among larger construction consultancies in being employee-owned: 2,400 of MMD's 16,000 employees own shares in the business. Employee 
ownership is a defining characteristic of MMD. The interviewed senior executive observes: "Our culture is influenced by the fact that we are employee owned. It shapes our attitude to risk - it is about our money. We are careful in our investments and acquisitions; we are careful about the terms and conditions that we accept". Employee ownership makes MMD "very risk aware. We drive a strong professional excellence message, which is essential to good client care and repeat business."

MMD has had a strong focus on organic growth over the period: "95\% of our growth has been organic". Based on MMD's experience of the early 1990s recession, their subsequent growth strategy has focused on developing a balanced risk profile, expanding sectorally and geographically. MMD has engaged in selective acquisitions. MMD uses M\&A as an initial step in the development of new markets: "We do not buy big firms; we do not mine volume, and we do not purchase similar firms. We buy smaller firms (usually no more than 300 people) and then support them to grow locally."

At times joint ventures (JVs) can lead to acquisitions, as with MMD's acquisition of Cambridge Education Associates (CEA). MMD had an interest in the education sector in the developing world, pursued via a JV with Cambridge University. Since the acquisition, the business offers general (non-engineering related) education consultancy. Success in the education sector prompted a focus on health and the acquisition of HLSP, an international health consultancy focused on governance and institutional strengthening, in 2003. The interviewee considers that this combination of engineering and policy capability is particularly important in the developing world, where "conventional thinking was once all about infrastructure, and then turned to human resources, and now we realise that both need to be developed together to deliver lasting solutions."

\section{Outlier \#2: Arup}


Arup is one of the world's best known and respected engineering consultancies, ranked \#7 in Building's top 200 Consultants in 2013. Formed by Ove Arup in 1946, it initially focused on structural engineering, and subsequently expanded into a multidisciplinary consultancy, whilst maintaining an engineering focus. Arup has grown significantly since 1990 - the firm was ranked \#1 among the Building Consultants in 1988 and has been among the top ten firms each year since then. Today, there are 18 operating businesses focused on end-markets, organised globally across five regions. Group income in 2011-12 was some $£ 991$ million, profits at $£ 31$ million with worldwide staff of 10,135 .

Among similar-sized construction consultancy firms, Arup is also unusual in being owned by a Trust on behalf of its employees. This grants the firm independence; it has no shareholders or external investors. Arup is also well known for its tradition of innovation and excellence, boasting a legacy of involvement in many of the world's most prestigious and iconic buildings and engineering structures, including the Sydney Opera House.

The senior executive interviewee noted the influence of the founder on the current business: "many employees quote the "key speech", though paradoxically this is probably the antithesis of what Ove Arup would have wanted; he wanted people to think for themselves!" Nonetheless, the ownership structure - the Arup Trust - argued in the 'key speech' and the focus on innovation, creativity and excellence remain: "[Ove Arup] wanted to create a place where good people like to work together... the partners transferred their ownership into a trust that was engineered to make a future [hostile] takeover difficult." This particular form of ownership has been crucial to the firm's growth and success: "everything is driven by excellence. No one has "skin in the game" [in the conventional sense of a financial shareholding] ... and growth is more a function of letting good people do what they want to do... provided they don't lose money!"

\footnotetext{
1 an address Ove Arup made to the firm's partners in 1970 setting out important guiding principles including independence and firm ownership, and a belief in excellence - http://www.arup.com/Publications/The_Key_Speech.aspx
} 
The interviewed executive recognised that growth is important to any modern business; “... in Arup it creates opportunities for bright young people - you cannot cap growth." He also acknowledged that scale is important for large, challenging global projects, especially in sectors like rail and other infrastructure. He noted, though, that Arup is "about doing interesting things, not about "bums on seats". Engineering is really about the broader agenda, for example, developing on a city scale, and asking the exciting questions that cut across disciplines of design, finance, economics, management."

Growth has been mainly organic, but has involved some strategic acquisitions to help develop business in new service areas. The interviewee agreed that growth was as much - if not more - a consequence of the firm's development rather than an explicit strategy: “... growth comes from the coalface. The San Francisco office, for example, has the freedom to grow, provided they adhere to the guiding principles, but they are not given explicit growth objectives from the top." Acquisitions are 'frequently discussed at top level' in Arup, but the key philosophy is to hire good people who are innovative and strive for excellence, rather than to acquire firms that might carry a mixture of talent. That said, Arup's largest acquisition was of the West Midlands Road Construction Unit, a public sector highways consultancy in the 1970s (about 100 people strong, at a time when Arup employed about 1000) which helped Arup to move into the transportation sector. He noted that the subsequent integration of that business took many years and was only fully completed when Arup acquired another midlands-based business and merged both, relocating them eventually to Arup's new Midlands Campus in 2001. Since then, acquisitions have been of much smaller businesses "5 to 20 people, nothing that would change the shape of the firm" and that these were used "usually when we were trying to get a new services off to a flying start." For example, Arup acquired a small tunnelling business in the early 1980s that became successful and helped the firm ultimately to become involved e.g. in the Channel Tunnel Rail Link and Crossrail. 


\section{Outlier \#3: Mace}

Though ranked \#9 in the Building Top 200 Consultants in 2013, Mace is one of the more unusual and fastest growing businesses in the sample of firms studied for this paper. Formed in 1990 by Ian McPherson and four colleagues from Bovis - a major contracting firm - this niche consultancy offered construction management services on high value commercial development. It soon focused on project management consultancy which provided most of its rapid growth through the 1990s, and by the end of the decade had undertaken significant international expansion focusing on Europe and the Middle East. As in the 1990s, growth in the 2000s was primarily organic, though sometimes supplemented by small, strategic acquisitions to support a strategy of service diversification. In 2001 a Management Buy Out (MBO) led by 12 senior managers transferred control of Mace from the initial founder/owners, some of whom retired at that time. In the 24 years since it was formed, Mace has grown staff numbers yearly and in 2014 employs 4,200 personnel worldwide. Group turnover in 2013 was $£ 1.1 \mathrm{bn}$, approximately $£ 900 \mathrm{~m}$ of which was in contracting. Mace remains privately owned.

What sets Mace apart from its peer group in Building's top 200 is the extent of its construction contracting activity. The senior executive interviewed at the end of 2013 considers its consultancy and contracting activities as "equally important and mutually supportive." The interviewee acknowledges that the willingness on the part of Mace's owners to take construction risk, together with their innate entrepreneurialism are essential elements in the firm's approach to growth: "essentially, we let good people get on with it". Each of the 12 directors involved in the MBO in 2001 were "keen to do their own thing and to develop their own parts of the business" and the number and range of operating companies formed in the early part of the 2000s reflects their diverse interests. However, the approach led to a loss of control over some of the overseas operating businesses: "many people were 
off doing their own thing - not necessarily the wrong thing, but not always in the interests of the wider business either", and by 2012 it was decided to merge the International and Consultancy businesses to "rein it all back in".

Owner/Directors were all very ambitious, focused on growth and keen to set challenging growth targets: "we wanted to earn $£ 100$ million in consultancy, and $£ 400$ million in contracting by 2006 - very stretching back in 2001. We got there by 2007." "Mace is all about organic growth". The high level of recruitment required in growing organically is what led the firm to form its own HR consultancy, Mace People, in 2004, though smaller acquisitions were also involved. Two of these $-\mathrm{fm} 24$, a niche Facilities Management business; and C2C, a specialist Regeneration Consultancy in the North West of England - helped Mace develop market share and enter new markets. The fm 24 business had proprietary helpdesk software that Mace needed for its own growing FM business; C2C had close ties with the masterplanning consultants on the London 2012 programme and helped Mace to become more involved in that programme, as well as supporting the development of Mace business in the North West.

\section{Cross-case comparison of the outlier firms}

Positioned amid UK's top ten construction consultancies, the three firms are outliers, as they have maintained a high industry ranking with a selective acquisition programme consisting of targeted, small-scale transactions into new sectors or markets. In contrast to other major CPSFs, the three studied outliers are privately owned, be it via an employee ownership scheme (Arup), an employee shareholder scheme (Mott Macdonald) or private ownership (Mace). Interviewees concurred that their mode of ownership drives their approach to growth, and hence their selective acquisitive behaviour. For Arup, growth is not explicitly sought, but is considered as a natural outcome of excellent engineering. Mott Macdonald and Mace focus on growth, yet merging or acquiring are not prioritized. As the firms' owners are close to the 
firms' operations, the firms are risk averse and avoid unnecessary acquisitions. Where conducted, acquisitions have enabled growth into new market or business segments.

The driver of success across the three outliers can be traced to the firms' organizational cultures. Professional excellence, innovation, entrepreneurship, customer satisfaction and financial savvy exemplify the firms' values. Interviewees acknowledged that the organization's values drive employee behaviour, this providing a foundation for business operations. Dependent on knowledge, these firms strive for professional excellence and ongoing competence development. Seeking breakthrough solutions requires innovation, as visible in Arup's case. Mace illustrates the significance of entrepreneurship. The firms see profitability as stemming from addressing customer concerns, hence a focus on customer needs is priority. Private ownership and the closeness of owners to the business translates into financial awareness and commercial savvy. Strong corporate cultures appear to enable these firms to tap into their human capital resources through organic growth, instead of relying on the purchase of other firms (and new human resources) via M\&As.

\section{CONCLUSIONS AND DISCUSSION}

\section{Implications for construction economics and management}

Extending on Kreitl et al. (2002) and Kreitl and Oberndofer (2004), our first contribution to the discipline of construction economics is to consider the construction professional services sector not as a static monolith, but as one that is undergoing a transformation from small to larger-sized, single to multidisciplinary, domestic to international, and privately-owned to publicly-listed businesses. Whilst this evolution has been gradual throughout the $20^{\text {th }}$ century, its pace has accelerated since the mega-mergers of the early 1990s and the subsequent wave of acquisitions. The 1988-2013 period has been coupled with legislative changes, deregulation, privatization and outsourcing in the UK (Connaughton and Meikle, 2013) set amid a global landscape of liberalization of world trade (Kolev et al., 2012; Fairclough and 
Fairclough, 2012). The rapid pace of the sector's change 1988-2013 begs the question - have academics and practitioners kept pace? Do we understand the sector's competitive dynamics? Do existing economic theories of the construction sector hold, and if not, what amendments are needed? We join Chinowsky and Meredith's call (2000) for an enhanced focus on construction firm strategies and strategic management in the sector.

Our second contribution is to highlight that this growth is not evenly spread across CPSFs. Across the sample of 25, we identified distinctive growth profiles with respect to (1) serial acquirers, (2) occasional acquirers, and (3) organic growth. Mergers occurred amid the largest players particularly in the early 1990s, whereas thereafter growth has been achieved across the sector largely via a series of acquisitions alongside organic growth. It appears, though, that M\&A activity is prevalent amid public limited companies (PLCs). As the majority of the turnover of the CPSF sector is carried out by the smaller-sized practices, looking into the future, we can expect more of these small practice to be subsumed by the larger players.

Our third contribution relates to organic growth. Within the top 10 firms we identified three outliers in that they have secured a top industry position without resorting to active acquisitive growth. Instead, they have been led by private ownership, a careful approach to external investments, a focus on unleashing internal talent and organizational culture driving firm growth. Yet these three firms are consistently highly ranked in the league tables. This raises interesting questions, both for academics and practitioners: whether M\&A or organic growth strategies offer routes to improved business performance remains open to debate.

Going forward, beyond an appreciation of growth strategies, the issue of managing firms that have grown via acquisitions (Barkema and Schijven, 2008; Teerikangas, 2012) deserves recognition. This concerns the larger firms described as serial acquirers. For them, beyond firm growth, acquisitions translate into a question of organizational integration and 
design (Lawrence and Lorsch, 1967): how to manage a firm grown via acquisitions, boasting a multiplicity of histories, cultures and identities (Teerikangas, 2012)? If CPSFs have changed and feature within-organizational complexity, what are the implications for firm performance (Barkema and Schijven, 2008) and, beyond, for construction economics? Do firms have the management capacity to deal with numerous acquisitions (Penrose, 1959; Gruneberg and Ive, 2000)? Can firms acquire a limitless number of firms, or is there a breakoff point to the absorptive capacity of an acquiring firm (Barkema and Schijven, 2008)? The bi-disciplinary remit of $C M E$ is relevant in the study of firm growth and $\mathrm{M} \& \mathrm{~A}$, as these phenomena span disciplinary boundaries. Going forward, there is a need for research spanning the economic, strategic, and sociocultural boundaries of firm growth (Faulkner et al., 2012).

\section{Implications for theorizing on M\&A}

Further, our findings offer three implications for M\&A theorizing. Firstly, whilst M\&A research focuses on active acquirers and thus propels a myth of merger mania, we observe different (i.e. three) growth profiles amid the top 25 UK-based CPSFs. Mergers are prevalent amid the largest firms in the sector. Acquisition activity reflects the ranking of the firms in the league tables - larger players are more active acquirers than the smaller ones, focused on organic growth. M\&A activity is thus unequally spread within the industry.

Secondly, the three outliers' success via organic growth deserves recognition. It resonates with Penrose's (1959) argument about the difficulty of absorbing firms following acquisitions. Whilst such outliers might be characteristic of CPSFs, reliant on human capital (von Nordenflycht, 2010), the findings resonate with the trend to leverage the human capital advantage of firms (Becker et al., 1997; Hatch and Dyer, 2004), manifest in developments in the resource-based view of the firm (Barney et al., 2001; Wright et al., 2001). If human capital resources matter, then the example of the three outliers bears significance. In a 
knowledge-based era, dependent on human capital, is the example of Arup, Mott MacDonald and Mace, consisting of careful acquisitions, private ownership, and a strong corporate culture one to abide by? In Penrose's (1959) terms - is the success of these firms due to their ability to make better use of their existing management capacity (Gruneberg and Ive, 2000)?

Finally, there is a need to attend to industry, profession and firm size dynamics in M\&A theorizing. Instead of force-fitting M\&A as 'the' main mode of corporate growth (see also Faulkner et al., 2012; Ryan, 2012), the findings attest to entrepreneurial and engaged cultures as offering an alternative explanation for firm growth. Is it time to revisit Penrose (1959) and re-consider strategies for firm growth? Are the identified growth patterns idiosyncratic to the $21^{\text {st }}$ century construction professional services sector (Gruneberg and Ive, 2000) or do they resonate across industries and professions? Whilst having momentum, we acknowledge that our findings remain tentative. We look forward to an engaging and intellectually stimulating future research agenda. 


\section{REFERENCES}

Ahuja, G., and Katila, R. (2001) Technological acquisitions and the innovation performance of acquiring firms: a longitudinal study. Strategic Management Journal, 22(3), 197-220.

Andrade, G., Mitchell, M. \& Stafford, E. (2001) New Evidence and Perspectives on Mergers Journal of Economic Perspectives, 15, 103-120.

Angwin, D. (2012) Merger and acquisition typologies: A review, in Faulkner, D., Teerikangas, S., and Joseph, R. (eds), The Handbook of Mergers and Acquisitions, Oxford: Oxford University Press, pp. 566-592.

Barkema, H. G., and Schijven, M. (2008) Toward unlocking the full potential of acquisitions: The role of organizational restructuring. Academy of Management Journal, 51(4), 696722.

Barney, J., Wright, M., and Ketchen, D. J. (2001) The Resource-based View of the Firm: Ten Years after 1991. Journal of Management, 27, 625-641.

Bartunek, J.M. and Louis, M.R. (1996) Insider/Outsider Team Research. Thousand Oaks, CA: Sage.

Becker, B. E., Huselid, M. A., Pickus, P. S. and Spratz, M. F. (1997) HR as a Source of Shareholder Value: Research and Recommendations. Human Resource Management, 36(1), 39-47.

Borys, B., and Jemison, D. B. (1989) Hybrid arrangeements as strategic alliances: Theoretical issues in organizational combinations. Academy of Management Review, 14(2), 234-249.

Brock, D. M. (2006) The changing professional organization: a review of competing archetypes. International Journal of Management Reviews, 8, 157-174.

Bröchner, J., Rosander, S. and Waara, F. (2004) Cross-border post-acquisition knowledge transfer among construction consultants. Construction Management and Economics, 22(4), 421-427.

Buckley, P. J. and Ghauri, P. N. (2002) International Mergers and Acquisitions: A Reader. London: Thomson.

Carrillo, P. (2001) Mergers and acquisitions in the construction industry: An exploratory study. PhD thesis, Loughborough University.

Connaughton, J. and Meikle, J. (2013) The changing nature of UK construction professional servicesfirms. Building Research and Information, 41(1), 95-109.

Cartwright, S., Teerikangas, S., Rouzies, R. and Evered-Wilson, E. (2012) Methods in M\&A: A look at the past, and the future, to forge a path forward. Scandinavian Journal of Management, 28(2), 95-106.

Cheah, C. Y. J., Garvin, M. J. and Miller, J. B. (2004) Empirical study of strategic performance of global construction firms. Journal of Construction Engineering and Management, 130(6), 808-817.

Chinowsky, P. S. and Meredith, J. E. (2000) Strategic management in construction. Journal of Construction Engineering and Management, 126(1), 1-9.

Corley, K. G. and Gioia, D. A. (2011) Building theory about theory building: What constitutes a theoretical contribution? Academy of Management Review, 36(1), 12-32. 
Dymski, G. A. (2012) Financial mergers and acquisitions: From regulation to strategic repositioning and geo-economics, in Faulkner, D., Teerikangas, S., and Joseph, R. (eds) The Handbook of Mergers and Acquisitions, Oxford University Press, Oxford, pp. 566592.

Delaney, F. T. \& Wamuziri, S. C. (2004) The impact of mergers and acquisitions on shareholder wealth in the UK construction industry. Engineering, Construction and Architectural Management, 11(1), 65-73.

Eisenhardt, K. (1989) Building theories from case study research. Academy of Management Review, 14(4), 532-550.

Empson, L. (2001) Fear of contamination and fear of exploitation: Impediments to knowledge transfer in mergers of professional services firms. Human Relations, 54(7), 839-862.

Fairclough, N. C. and Fairclough, S. (2012) Mergers between professional services firms: How the 'Big Eight' became the 'Big Five', in Faulkner, D., Teerikangas, S., and Joseph, R. (eds) The Handbook of Mergers and Acquisitions, Oxford University Press, Oxford, pp. 593-618.

Faulkner, D., Teerikangas, S. and Joseph, R. (2012) The Handbook of Mergers and Acquisitions. Oxford University Press, Oxford.

Ghauri, P. N. and Buckley, P. G. (2003) International mergers and acquisitions: Past, present and future, in Cooper, C. and Finkelstein, S. (eds), Advances in Mergers and Acquisitions (Volume 2), Emerald Group Publishing Limited, pp. 207-229.

Gialketsis, M. P. (1991) Integration planning for merger of two consulting engineering firm. Journal of Management in Engineering , 7(3), 279-294.

Glaser, B. J. and Strauss, A. L. (1967) The Discovery of Grounded Theory. Chicago, IL: Aldine Publishing Company.

Ghauri, P. N. \& Buckley, P. J. (2003) International mergers and acquisitions: Past, present and future. Advances in Mergers and Acquisitions, 2, 207-229.

Graebner, M. E., Eisenhardt, K. M. and Roundy, P. T. (2010) Success and failure in technology acquisitions: Lessons for buyers and sellers. Academy of Management Perspectives, 24(3), 73-92.

Greenwood, R., Hinings, C. R. and Brown, J. (1994) Merging professional services firms. Organisation Science, 5(2), 239-257.

Gruneberg, S.L. and Ive, G. J. (2000) The Economics of the Modern Construction Firm. London, Macmillan.

Haleblian, J., Devers, C. E., McNamara, G., Carpenter, M. A. and Davison, R. B. (2009) Taking stock of what we know about mergers and acquisitions: a review and research agenda. Journal of Management, 35, 469-502.

Hatch, N. W. and Dyer, J. H. (2004) Human Capital and Learning as a Source of Sustainable Competitive Advantage. Strategic Management Journal, 25, 1155-1178.

Hensey, M. (1992) Thoughts on the management of acquisitions. Journal of Management in Engineering, 8(2), 130-137.

Hensey, M. (2000) A few 'lessons learnt' from acquisitions. Journal of Management in Engineering, 16(4), 36-38. 
Ive, G. and Gruneberg, S. L. (2000) The economics of the modern construction sector. London: Palgrave Macmillan.

Jewell, C., Flanagan, R. and Anac, C. (2010) Understanding UK construction professional services exports: definitions and characteristics. Construction Management and Economics, 28, 213-239

Lamberg, J-A and Tikkanen, H. (2006) Changing sources of competitive advantage: cognition and path dependence in the Finnish retail industry. Industrial and Corporate Change, 15 (5), 811-846

Hitt, M., King, D., Krishnan, H., Makri, M., Schijven, M., Shimizu, K. and Zhu, H. (2012) Creating value through mergers and acquisitions: Challenges and opportunities, in Faulkner, D., Teerikangas, S., and Joseph, R. (eds) The Handbook of Mergers and Acquisitions. Oxford: Oxford University Press, pp. 71-113.

Kale, P., Singh, H. and Raman, A. P. (2009) Don't integrate your acquisitions, partner with them. Harvard Business Review, December, 109-115.

Keil, T., Laamanen, T. and Makisalo, A. (2012) Acquisitions, acquisition programs, and acquisition capabilities, in Faulkner, D., Teerikangas, S., and Joseph, R. (eds) The Handbook of Mergers and Acquisitions, Oxford: Oxford University Press, pp. 148-170.

Kolev, K., Haleblian, J. and McNamara, G. (2012) A Review of the Merger and Acquisition Wave Literature: History, Antecedents, Consequences and Future Directions, in Faulkner, D., Teerikangas, S. and Joseph, R. (eds) The Handbook of Mergers and Acquisitions, Oxford: Oxford University Press, pp. 19-39.

Kreitl, G., Urschiftz, G. and Oberndorfer, W. J. (2002) Corporate growth of engineering consulting firms: a European review. Construction Management and Economics, 20(5), 437-448.

Kreitl, G. and Oberndorfer, W. J. (2004) Motives for acquisitions among engineering consulting firms. Construction Management and Economics, 22(7), 691-700.

Laamanen, T. and Keil, T. (2008) Performance of serial acquirers: toward an acquisition program perspective. Strategic Management Journal, 29(6), 663-672.

Lawrence, P., and Lorsch, J. (1967) Differentiation and integration in complex organizations. Administrative Science Quarterly, 12, 1-30.

Lowe, J. (2011) 'Concentration in the UK construction sector', Journal of Financial Management of Property and Construction, 16, 3, pp232-248

Mace, M. L., Montgomery, G. (1962) Management Problems of Corporate Acquisitions. Cambridge: Harvard University Press.

Maister, D. H. (1993) Managing the professional services firm. New York: Free Press.

Meikle, J. (2011) Changes in the UK construction professional services firms in the late 20th century, in Smyth, H., Managing the professional practice in the built environment, Chichester: Wiley-Blackwell, pp. 315-328.

Parmigiani, A. and M. Rivera-Santos. (2011) Clearing a path through the forest: A metareview of interorganizational relationships. Journal of Management, 37(4), 1108-1136.

Penrose, E. (1959) The theory of the growth of the firm. Oxford: Oxford University Press.

Ranft, A. L. and Lord, M. D. (2002) Acquiring new technologies and capabilities: A grounded model of acquisition implementation. Organization Science, 13(4), 420. 
Ryan, B. (2012) Shareholder value: A driver of merger and acquisition activity, in Faulkner, D., Teerikangas, S., and Joseph, R. (eds) The Handbook of Mergers and Acquisitions, Oxford: Oxford University Press, pp. 320-338.

Smyth, H. (2011) Managing the professional practice in the built environment. Chichester: Wiley-Blackwell.

Stake, R. E. (1995) The art of case study research. London: Sage

Teerikangas, S. (2012) Silent forces shaping the performance of cross-border acquisitions, in Faulkner, D., Teerikangas, S., and Joseph, R. (eds) The Handbook of Mergers and Acquisitions, Oxford: Oxford University Press, pp. 517-544.

von Nordenflycht, A. (2010) What is a professional services firm? Toward a theory and taxonomy of knowledge-intensive firms. Academy of Management Review, 35, 155-174

Walsh, J. P., Meyer, A. D. and Schoonhoven, C. B. (2006) A Future for Organization Theory: Living in and with changing organizations. Organization Science, 17(5), 657-671.

Wright, P. M., Dunford, B. B. and Snell, S. A. (2001) Human Resources and the Resource Based View of the Firm. Journal of Management, 27, 701-721.

Yin, R, K. (2004) Case study research Thousand Oaks: Sage Publications. 


\section{APPENDICES}

Table 1: Our sample of firms.

\begin{tabular}{|c|c|}
\hline \multicolumn{2}{|c|}{ Firms sampled for the study } \\
\hline 1 & Atkins \\
\hline 2 & Mott MacDonald \\
\hline 3 & URS \\
\hline 4 & Aecom \\
\hline 5 & Arcadis (i.e. EC Harris) \\
\hline 6 & Jacobs UK \\
\hline 7 & Arup \\
\hline 8 & Turner and Townsend \\
\hline 9 & Mace \\
\hline 10 & WSP UK (Genivar) \\
\hline 11 & Parsons Brinckerhoff \\
\hline 12 & Waterman \\
\hline 13 & Gleeds \\
\hline 14 & Sweett Group \\
\hline 15 & Ramboll \\
\hline 16 & NPS Property Consultants \\
\hline 17 & BDP \\
\hline 18 & Foster and Partners \\
\hline 19 & Buro Happold \\
\hline 20 & TPS (Carillion) \\
\hline 21 & Hoare Lea \\
\hline 22 & Systech Intl \\
\hline 23 & Fairhurst \\
\hline 24 & WYG \\
\hline 25 & Grontmij \\
\hline & \\
\hline
\end{tabular}


Table 2: Top construction professional services (i.e. consulting) firms in 1989 vs. 2012. (**)

\begin{tabular}{|c|c|c|c|c|c|c|c|c|c|c|}
\hline \multirow[b]{2}{*}{ Rank } & \multicolumn{5}{|c|}{1989 data (from Building magazine $1988,1989,1990)(*)$} & \multicolumn{5}{|c|}{2012 data (from Building magazine 2013) } \\
\hline & Firm & 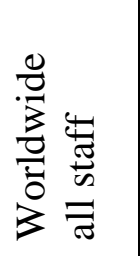 & 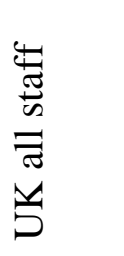 & 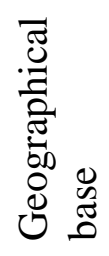 & 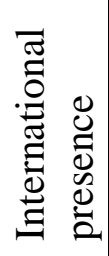 & Firm & 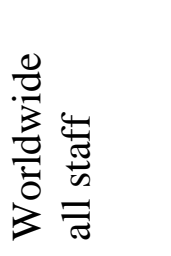 & 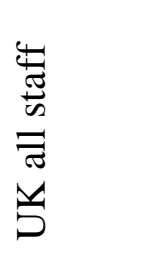 & 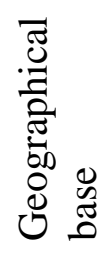 & 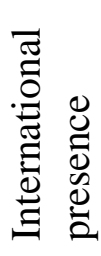 \\
\hline 1 & The Ove Arup Partnership & 3,833 & 3,004 & UK & $78 \%$ & Jacobs En & 62,500 & 8,274 & US & $13 \%$ \\
\hline 2 & Mott MacDonald Group & 2,703 & 1,851 & UK & $68 \%$ & URS & 54,000 & 7,012 & US & $13 \%$ \\
\hline 3 & WS Atkins & 2,013 & 1,743 & UK & $87 \%$ & Aecom & 44,985 & 4,016 & US & $9 \%$ \\
\hline 4 & $\begin{array}{l}\text { Scott Wilson Kirkpatrick \& } \\
\text { Partners }\end{array}$ & 1,700 & 1,100 & UK & $65 \%$ & EC Harris/ Arcadis & 22,000 & 2,578 & NL & $12 \%$ \\
\hline 5 & WT Partnership & 1,590 & 472 & UK & $30 \%$ & Atkins & 17,899 & 9,374 & UK & $52 \%$ \\
\hline 6 & Building Design Partnership & 1,453 & 1,414 & UK & $97 \%$ & WSP & 14,924 & 2,023 & Can. & $14 \%$ \\
\hline 7 & $\begin{array}{l}\text { Sir William Halcrow \& } \\
\text { Partners }\end{array}$ & 1,419 & 1,193 & UK & $84 \%$ & Mott MacDonald & 14,912 & 5,398 & UK & $36 \%$ \\
\hline 8 & Davis Langdon \& Everest & 1,306 & 672 & UK & $51 \%$ & Parsons Brinckerhoff & 14,219 & 1,832 & UK & $13 ?$ \\
\hline 9 & Gibbs & 1,209 & 841 & UK & $70 \%$ & Arup Group & 11,233 & 3,716 & UK & $33 \%$ \\
\hline 10 & Travers Morgan & 892 & 847 & UK & $95 \%$ & Capita Symonds & 3,997 & 3,975 & UK & $99 \%$ \\
\hline & Totals & 18,118 & 13,137 & -- & $73 \%$ & & 260,659 & 48,198 & -- & $19 \%$ \\
\hline
\end{tabular}

Source: Based on Building data in 1988, 1989, 1990 and 2013

Note: Ranking is based on the numbers of worldwide staff.

Legend:

(*) Although the early data was published in 1988, 1989 and 1990, it referred to earlier periods, probably a year earlier. The intention of averaging the early years' data is to secure the inclusion of the largest firms of the period.

(**) General practice surveying firms have been omitted from the table on the grounds that they are property, rather than construction, consulting firms. 
Table 3. Concentration in Construction professional services firms, 1997 - 2013

\begin{tabular}{|l|c|c|c|}
\hline Concentration & $\mathbf{1 9 9 7}(*)$ & $\mathbf{2 0 0 5}$ & $\mathbf{2 0 1 3}$ \\
\hline $\begin{array}{l}\text { Share of top 50 revenue taken } \\
\text { by top 5 firms }\end{array}$ & 35.9 & 38.6 & 46.2 \\
\hline $\begin{array}{l}\text { Share of top 50 revenue taken } \\
\text { by top 4 firms }\end{array}$ & 32.6 & 34.8 & 40.8 \\
\hline Number of gaps in data (**) & 13 & 8 & 7 \\
\hline
\end{tabular}

Source: Based on Building data, various years.

Legend:

(*): We start the analysis in 1997. This is when financial data was introduced into the league tables.

$(* *)$ : Where gaps in the revenue data existed, these have been filled by taking the mean of the values for the firms above and below in the rankings. The number of gaps reduces over time. This might indicate less sensitivity in the firms concerning the publication of financial data. Most of the larger firms will be required to produce annual figures, but this is less evident further down the list for the smaller practices. 
Table 4: Corporate growth profiles within top construction PSFs 1988-2013.

\begin{tabular}{|c|c|}
\hline \multicolumn{2}{|c|}{ Profile I: Active merger and acquisition activity } \\
\hline Profile type & Ranking (2013)/ name \\
\hline $\begin{array}{l}\text { Growth by merger(s) and serial } \\
\text { acquisitions }\end{array}$ & $\begin{array}{l}\text { 4/Aecom } \\
\text { 5/Arcadis } \\
6 / \mathrm{Jacobs} \\
\text { 10/WSP }\end{array}$ \\
\hline Growth by serial acquisitions & $\begin{array}{l}\text { 1/Atkins } \\
\text { 3/URS } \\
\text { 15/Ramboll } \\
\text { 24/WYG }\end{array}$ \\
\hline \multicolumn{2}{|l|}{ Profile II: Occasional acquirers } \\
\hline $\begin{array}{l}\text { Growth by merger and occasional } \\
\text { acquisitions }\end{array}$ & 2/Mott MacDonald \\
\hline Growth by occasional acquisitions & $\begin{array}{l}\text { 7/Arup } \\
\text { 9/Mace } \\
\text { 11/Parsons Brinckerhoff } \\
\text { 12/Waterman } \\
\text { 13/Gleeds } \\
\text { 16/NPS Property Consultants } \\
\text { 25/Grontmij }\end{array}$ \\
\hline Growth by mergers & 20/TPS \\
\hline \multicolumn{2}{|l|}{ Profile III: Organic growth } \\
\hline Organic growth & $\begin{array}{l}\text { 8/Turner and Townsend } \\
\text { 14/Sweett Group } \\
\text { 17/BDP } \\
\text { 18/Foster and Partners } \\
\text { 19/Buro Happold } \\
\text { 21/Hoare Lea } \\
\text { 22/Systech International } \\
\text { 23/Fairhurst }\end{array}$ \\
\hline
\end{tabular}


Table 5: Mode of ownership and profile of corporate growth

\begin{tabular}{|c|c|c|c|}
\hline & $\begin{array}{l}\text { Profile I: Active } \\
\text { merger and } \\
\text { acquisition } \\
\text { activity }\end{array}$ & $\begin{array}{l}\text { Profile II: } \\
\text { Occasional } \\
\text { acquirers }\end{array}$ & $\begin{array}{l}\text { Profile III: } \\
\text { Organic growth }\end{array}$ \\
\hline Star & & 9/Mace & $\begin{array}{l}\text { 18/Foster and } \\
\text { Partners }\end{array}$ \\
\hline Employee owned & & $\begin{array}{l}\text { 2/Mott } \\
\text { Macdonald } \\
\text { 7/Arup }\end{array}$ & \\
\hline P2 (partnership) & 15/Ramboll & 13/Gleeds & $\begin{array}{l}\text { 8/Turner and } \\
\text { Townsend } \\
\text { 17/BDP } \\
\text { 19/Buro Happold } \\
\text { 21/HoareLea } \\
\text { 22/Systech } \\
\text { International } \\
\text { 23/Fairhurst }\end{array}$ \\
\hline $\begin{array}{l}\text { Globalized professional } \\
\text { network (GPN) }\end{array}$ & $\begin{array}{l}\text { 1/Atkins } \\
\text { 3/URS } \\
\text { 4/Aecom } \\
\text { 5/Arcadis } \\
\text { 6/Jacobs } \\
\text { 10/WSP } \\
\text { 24/WYG }\end{array}$ & $\begin{array}{l}\text { 11/Parsons } \\
\text { Brinckerhoff } \\
\text { 12/Waterman } \\
\text { 20/TPS } \\
\text { 25/Grontmij }\end{array}$ & 14/Sweett Group \\
\hline Local council owned & & $\begin{array}{l}\text { 16/NPS Property } \\
\text { Consultants }\end{array}$ & \\
\hline
\end{tabular}

Legend: The ownership categorization as regards the terms star, partnership and globalized professional network is based on Connaughton and Meikle (2013) and Brock (2006). 
Table 6: Disciplinary reach and profile of corporate growth

\begin{tabular}{|c|c|c|c|}
\hline & $\underline{\text { Single discipline }}$ & $\begin{array}{l}\text { Multidisciplinary } \\
\text { narrow }\end{array}$ & Multidisciplinary broad \\
\hline \multicolumn{4}{|c|}{ Profile I: Active merger and acquisition activity } \\
\hline $\begin{array}{l}\text { Growth by } \\
\text { merger(s) and } \\
\text { serial } \\
\text { acquisitions }\end{array}$ & & & $\begin{array}{l}\text { 4/Aecom } \\
\text { 5/Arcadis } \\
\text { 6/Jacobs } \\
\text { 10/WSP }\end{array}$ \\
\hline $\begin{array}{l}\overline{\text { Growth by }} \\
\text { serial } \\
\text { acquisitions }\end{array}$ & & 15/Ramboll & $\begin{array}{l}\text { 1/Atkins } \\
\text { 3/URS } \\
\text { 24/WYG }\end{array}$ \\
\hline \multicolumn{4}{|c|}{ Profile II: Occasional acquirers } \\
\hline $\begin{array}{l}\text { Growth by } \\
\text { merger and } \\
\text { occasional } \\
\text { acquisitions }\end{array}$ & & 2/Mott MacDonald & \\
\hline $\begin{array}{l}\overline{\text { Growth by }} \\
\text { occasional } \\
\text { acquisitions } \\
\end{array}$ & & $\begin{array}{l}\text { 9/Mace } \\
\text { 11/Parsons Brinckerhoff } \\
\text { 12/Waterman } \\
\text { 13/Gleeds } \\
\text { 16/NPS Property } \\
\text { Consultants } \\
\text { 25/Grontwij }\end{array}$ & 7/Arup \\
\hline $\begin{array}{l}\text { Growth by } \\
\text { mergers }\end{array}$ & & 20/TPS & \\
\hline \multicolumn{4}{|c|}{ 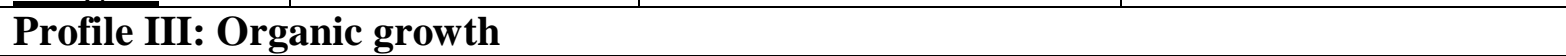 } \\
\hline$\frac{\text { Organic }}{\text { growth }}$ & $\begin{array}{l}\text { 18/Foster and } \\
\text { Partners } \\
\text { 21/Hoare Lea } \\
\text { 22/Systech } \\
\text { International } \\
\text { 23/Fairhurst }\end{array}$ & $\begin{array}{l}\text { 8/Turner and Townsend } \\
\text { 14/Sweett Group } \\
\text { 17/BDP } \\
\text { 19/Buro Happold }\end{array}$ & \\
\hline
\end{tabular}


Table 7: International reach vs. mode of growth

\begin{tabular}{|c|c|c|c|}
\hline & $\begin{array}{l}\text { Profile I: Active } \\
\text { merger and } \\
\text { acquisition activity }\end{array}$ & $\begin{array}{l}\text { Profile II: } \\
\text { Occasional acquirers }\end{array}$ & $\begin{array}{l}\text { Profile III: Organic } \\
\text { growth }\end{array}$ \\
\hline $\begin{array}{l}\text { International } \\
\text { presence }\end{array}$ & $\begin{array}{l}\text { 1/Atkins } \\
\text { 3/URS } \\
\text { 4/Aecom } \\
\text { 5/Arcadis } \\
\text { 6/Jacobs } \\
\text { 10/WSP }\end{array}$ & $\begin{array}{l}\text { 2/Mott Macdonald } \\
\text { 7/Arup } \\
\text { 9/Mace } \\
\text { 11/Parsons } \\
\text { Brinckerhoff } \\
\text { 13/Gleeds } \\
\text { 15/Ramboll }\end{array}$ & $\begin{array}{l}\text { 8/Turner and } \\
\text { Townsend } \\
\text { 14/Sweett Group } \\
\text { 22/Systech } \\
\text { International }\end{array}$ \\
\hline $\begin{array}{l}\text { International } \\
\text { adjacent }\end{array}$ & $24 / \mathrm{WYG}$ & $\begin{array}{l}\text { 12/Waterman } \\
\text { 20/TPS } \\
\text { 25/Grontmij }\end{array}$ & $\begin{array}{l}\text { 17/BDP } \\
\text { 18/Foster and Partners } \\
\text { 19/Buro Happold } \\
\text { 21/Hoare Lea }\end{array}$ \\
\hline Home market & & $\begin{array}{l}\text { 16/NPS Property } \\
\text { Consultants }\end{array}$ & 23/Fairhurst \\
\hline
\end{tabular}

